\title{
VONZÁSOK ÉS VÁLASZTÁSOK: BÉCS ÉS BUDAPEST ORVOSKARI KAPCSOLATAI 1769-19451
}

\section{ELECTIVE AFFINITIES: THE MEDICAL FACULTIES OF VIENNA AND BUDAPEST 1769-1945}

\author{
FrankTibor \\ az MTA rendes tagja, professor emeritus, Ë̈tvös Loránd Tudományegyetem \\ frank.tibor@btk.elte.hu
}

A 70 éves Szögi László tiszteletére

\begin{abstract}
ÖSSZEFOGLALÁS
E cikk célja a bécsi és a budapesti orvoskar közötti komplex kapcsolatrendszer korai történetének felvázolása. A magyarországi egyetem orvosi kara a 17-19. században a bécsi modellt volt köteles követni. Az osztrák-magyar kiegyezés és a II. világháború között a korábbi egyoldalú mintakövetés kényszerének helyére lépő együttműködés sokféle formáját valósították meg.

A nagyszombati, majd budai és pesti egyetem orvosi képzése sokáig szigorú elöírások szerint bécsi mintára folyt, és - részben ennek következtében is - magyar diákok ezrei tanultak egészen vagy részidőben Bécsben. A kiegyezés után kialakult és megélénkült a két kar intézményes kapcsolata és többféle kooperációja. Elmondhatjuk, hogy ez a korszak a magyar és az osztrák orvosképzés együttműködésének aranykora volt, egészen a Il. világháborúig.

A bécsi és a budapesti orvoskar újabb kori termékeny kölcsönkapcsolata történelmi mintául szolgálhat külföldi és magyar egyetemek sokoldalú együttműködéséhez, viszonyuk egyidejüleg több irányban is gyümölcsöző kölcsönhatásának mai értékesítéséhez és értékeléséhez.
\end{abstract}

\section{ABSTRACT}

This article endeavours to present the early history of the ever changing complexities of cooperation between the medical schools of Vienna and Budapest. In the $17-19^{\text {th }}$ centuries the Hungarian medical faculty was compelled by the law to strictly follow the model of Vienna. Since the medical education at what was then the University of Pest imitated that of Vienna, thousands of Hungarian students felt the urge to study, fully or partially, in Vienna.

${ }^{1}$ E cikk egy változata német nyelven az Osztrák Tudományos Akadémia felkérésére készült, és annak Strukturen und Netzwerke. Medizin und Wissenschaft in Wien 1848-1955 címü kötetében jelent meg 2018-ban. 
After the Austro-Hungarian Compromise of 1867, however, the constraints of this one-sided imitation were replaced by a surprisingly many-sided cooperation. The relationship and, often, cooperation of the two faculties became much more balanced. It can be safely stated that the post-1867 period became the golden age of cooperation between Hungary and Austria, also in the field of medical education, quite until World War II.

The mutually advantageous relationship of the medical schools of Vienna and Budapest may serve as a rich historical example of foreign and Hungarian universities in general, a paradigm to be studied and used as a fruitful pattern of great advantage also today.

Kulcsszavak: Gerhard van Swieten, conformetur-elv, peregrináció, bécsi orvosi iskola, Bene- és Schordann-ösztöndíj

Keywords: Gerhard van Swieten, principle of conformetur, peregrination, Vienna medical school, Bene and Schordann-scholarships

\section{A MAGYAR ORVOSI FAKULTÁS}

A mai budapesti Eötvös Loránd Tudományegyetem (1921-től Királyi Magyar Pázmány Péter Tudományegyetem) Magyarország első és sokáig egyetlen egyeteme volt, jezsuita alapítása 1635-ben történt. Ezt a máig folyamatosan müködő magyar egyetemet Pázmány Péter kardinális alapította Nagyszombatban (ma Trnava, Szlovákia, németül Tyrnau), és irányítását a jezsuita rendre bízta.

Minthogy Magyarország középső részét megszállva tartotta az Oszmán Birodalom, az esztergomi érsek Nagyszombatba menekült. Ott, a törököktől érintetlenül és biztonságban maradt egykori magyar Felvidéken kívánt lehetőséget adni a magyar ifjúságnak felsőfokú ismeretek elsajátítására, a jórészt hódoltságban élő nemzetnek új magyar értelmiség kinevelésére. Nagyszombat közel van Pozsonyhoz (ma Bratislava), kevesebb mint $50 \mathrm{~km}$-es távolságra, és $110 \mathrm{~km}$-nyire fekszik Bécstől. Az oszmán hódítások korában kapu volt a Nyugat felé. Esztergomot a törökök 1543-ban elfoglalták, és a tőlük való félelem akkora volt, hogy a főkáptalan csak századok múltán, Rudnay Sándor hercegprímás rendeletére került ismét vissza. Az Orvosi Kar, amelyet Mária Terézia császárnő csak 1769-ben alapított meg, és csatolt a korábbi alapítású bölcsészeti (1635) és jogi (1667) karokhoz, azokkal együtt költözött 1777-ben Budára, majd az egész egyetemmel együtt 1784-ben Pestre. Az oktatás nyelve 1844 végéig a latin volt, ami a soknemzetiségű hallgatóság számára közvetítő nyelvnek számított. Az Orvosi Kart 1951-ben leválasztották a budapesti Tudományegyetemröl, és Budapesti Orvostudományi Egyetem (BOTE) néven önállóvá vált. A Semmelweis nevet 1969-ben vette fel, alapításának 200. évfordulóján lett Semmelweis Orvostudományi Egyetem (SOTE), mai nevén, 2000 óta Semmelweis Egyetem (SE). 


\section{A conformetur elve}

Az orvosi kar életében Mária Terézia nem csak az egyetem helyszínében eszközölt változtatást. 1766-ban megkezdte munkáját az a testület, amely az orvosi végzettségü nagy reformer, Gerhard van Swieten (1700-1772) javaslatára, a magyar királyi Helytartótanács tanulmányi bizottságaként alakult meg (H. Balázs, 1973, 154-163.). A bizottság egyik legfontosabb programpontja az volt, hogy a nagyszombati egyetemet minden tekintetben a bécsivel kell „,conformálni”, azaz bécsi mintára kell müködtetni (Győry, 1936, 23-24.; Schultheisz, 2005, 173.). A nagyszombati egyetemnek tehát a bécsi egyetem mására kellett szerveződnie, miután van Swieten a birodalom örökös tartományaiban müködő valamennyi egyetem reformját a bécsi modernizálásával kezdte (Győry, 1936, 53.). A magyar Helytartótanács 1771-ben kelt rendelete A nagyszombati egyetem statútumai címen természetesen latinul írta elő azt a követelményt, amely évszázados élete során a lehető legszorosabban kapcsolta össze a magyar tudományegyetem fakultásait a bécsiekkel: „A nagyszombati egyetem, melyet a király legmagasabb nevében és dicsőséges hatalmával újraalapoztak, úgy szabályzatát tekintve, mint valójában minden más tekintetben a bécsi egyetemmel hozandó teljes összhangzásba." Az egykori érseki egyetemböl királyi egyetem lett, élén van Swietennek az egyetemi reform terén legfőbb támaszával, galánthai gróf Fekete György alkancellárral mint „főigazgatóval”. A „,conformálás” Bécs centralisztikus törekvéseiből, uniformizáló igyekezetéből indult ki, s azt a tanulmányi szabályzat 1769 után ismételten megerősítette. A conformetur elvére való hivatkozással tették kötelezővé a magyar orvosi karon is a dékánválasztás bécsi mintájának követését (Győry, 1936, 38., 48.).

Egy 1749-ben kelt és 1755-ben megismételt legfelső elhatározás értelmében a bécsi orvosi diploma mindenütt érvényes volt, de Bécsben nem volt érvénye egyetlen más egyetem diplomájának sem (Győry, 1936, 55.). Ez a rendelkezés valamennyi örökös tartomány egyetemeire vonatkozott, éle tehát nem Nagyszombat ellen irányult, hatálya azonban az ottani diplomákra is kiterjedt. Van Swieten reformjai révén a bécsi egyetem ekkorra már valóban a legjobbnak számított a Habsburg Birodalomban, diplomája tehát ténylegesen értékesebb volt a birodalom minden más egyeteméénél.

Amikor a Helytartótanács tanulmányi bizottsága 1774-ben Gilg János nagyszombati városi fóorvosnak, a nagyszombati egyetem orvosi kara első igazgatójának felségfolyamodványát tárgyalta a kar oktatási gondjairól, a folyamodó hangsúlyozta, hogy annak idején azt a rendeletet kapta, hogy „mindenben a bécsi kar normáit kövesse" (Győry, 1936, 81.). Az általa képviselt egyetemi tanárok rendre előadták, hogy ennek az utasításnak maradéktalanul eleget is tettek. Gilg doktor azonban hozzáfüzte: a bécsi eskümintákat, rendszabályokat, a szokásrend leírását csak ,többszörös könyörgésekre” sikerült megkapnia, ezekröl viszont az derült 
ki, hogy kizárólag Bécsre gondolva fogalmazták meg őket - a nagyszombati viszonyok között alig voltak betủ szerint használhatóak (Győry, 1936, 81.). Gilg azonban nyilvánvalóan jól végezte a rábízott feladatokat: 1790-ben gilgenburgi előnévvel nemeslevelet kapott.

II. József (1741-1790) korában a tanulmányi bizottság ,az egyformaság érdekében" (Györy, 1936, 143.) csak a bécsi orvosi tankönyvek használatát engedte meg Pesten is (Buzinkay, 1977, 1., 29.). A bécsi minta kötelezö érvényü követése egészen az 1848-as forradalomig fennmaradt, amikor is az 1848: XIX. törvénycikk az egyetemet „egyenesen a [magyar] közoktatási minister hatósága alá” helyezte (Györy, 1936, 473.). Ezzel a magyar tudományegyetem kiszabadult a bécsi befolyás alól, és magyar nemzeti intézménnyé válhatott.

A magyar forradalom és szabadságharc leverése után azonban az egyetem tanulmányi rendje - még egyszer és utoljára - visszazökkent a conformetur elve alá. Leopold von Thun-Hohenstein gróf (1811-1888) osztrák kultusz- és oktatási minisztersége idején a bécsi orvosi kar felvirágzott, Pesten viszont siralmas viszonyokról értesülünk, egyszersmind újra kötelezővé tették a bécsi minta magyarországi követését (Győry, 1936, 504., 513.). Györy Tibor orvostörténész hangsúlyozza, hogy 1770-től 1848-ig, majd 1849-től egészen a conformetur elv 1867 utáni végleges érvénytelenné válásáig a bécsi központosítás oly módon érvényesült, hogy a mintakövetés elvét alig alkalmazták a pesti orvostudományi kar javára. A „conformálás” a gyakorlatban nem jelentette az oktatáshoz szükséges berendezés és felszerelés alapos fejlesztését, s az orvosi kart egyáltalában nem tekintették a tudományfejlesztés mühelyének. Győry hozzáteszi, hogy e tekintetben a helyzet nem volt más az örökös tartományok egyetemein sem (Győry, 1936, 504., 510., 525.). A hazai történeti irodalom egy része Magyarország helyzetét a Habsburg Monarchiában gyarmatinak, 1867 után félgyarmatinak mutatta be, s a bécsi és budapesti orvoskarok 17-19. századi viszonya ezen a különleges területen igazolni látszik ezt a sokat vitatott megközelítést (Hanák, 1975, 291-296.).

\section{PEREGRINÁCIÓ A MONARCHIÁBAN}

A külföldi magyar egyetemjárás, a peregrináció legfontosabb központja Bécs volt. A magyar diákok rendkívül nagy számban törekedtek arra, hogy orvosi tanulmányaikat a bécsi egyetemen végezzék. Bécs fölénye ugyan idővel csökkent a korábbi időszakhoz képest, de - mint azt a peregrináció kiváló kutatója, Szögi László megállapította - még mindig nagyon jelentős maradt (Szögi, 2000, 203208.). A bécsi egyetemre nemcsak a Monarchia egész területéről iratkoztak be szívesen a diákok, de a Balkán-félsziget új államaiból is nagy számban érkeztek.

Bécs nem csupán hírnevével vonzotta a magyar diákokat. A nyugat-magyarországi térség német anyanyelvủ lakossága, valamint a Pozsony, Moson, Sopron 
és Vas vármegyékben élő, németül jól beszélő zsidó családok is szívesen küldték fiaikat a Bécsi Egyetemre. (A Monarchia egyetemei ekkor még nem fogadtak nőhallgatókat.) 1867 és 1890 között összesen 7010 magyarországi hallgató érkezett az egyetemre, s ezek közül 3641, azaz a hallgatói csoport mintegy 52\%-a járt az Orvosi Karra. E tekintetben semmi sem változott a 19. század első feléhez képest. A bécsi magyar gyógyszerészhallgatók kétharmada német ajkú családokból származott, a bécsi magyar orvostanhallgatók 58\%-a jött zsidó családokból. Az igen jelentős érdeklődést többek között az magyarázta, hogy a bécsi diplomával Magyarországon is lehetett praktizálni, s hogy a hazai orvosképzés ekkor még jócskán elmaradt az európai élvonaltól (Szögi, 2015, 10-11., 35.). A Bécs valamely egyetemére vagy főiskolájára beiratkozó magyar hallgatók legnagyobb arányban (28\% százalékban) az orvosi képzés iránt érdeklődtek (Szögi, 2015, 25.). Szögi László az orvosképzés első helyét az 1851 utáni Bécs lukrativitásával magyarázza, ami által az egyéb külföldi orvosi felsőoktatás elveszítette vonzerejét (Szögi, 2015, 38.).

1867 és 1890 között az „Orvosok, sebészek, gyógyszerészek” kategória kiugróan első helyen szerepelt, 32,28\%-kal, utána következtek a „Jogászok, diplomaták” 19\%-kal, majd harmadikként a „Mérnökök, természettudósok, hadmérnökök” 14\%-kal. Szögi helyesen állapítja meg: „A külföldi tanulmányok egyre inkább postgraduális jelleget öltöttek [...] Egy másik újdonság a legújabb tudományágak iránti roppant érdeklődés volt, amit a gyorsan fejlődő magyar társadalom és gazdaság igényei magyaráztak" (Szögi, 2015, 41.).

A Szögi és kutatócsoportja által összeállított adattár (Patyi, 2004) világossá tette, hogy „az 1890-es év fordulópontnak tekinthető a magyarországi peregrinációban: ezután nőtt meg ugrásszerủen a németországi egyetemek és föiskolák jelentősége, és csökkent ezzel párhuzamosan a császárvárosi intézmények iránti érdeklődés”. Mindeközben azonban az is világossá vált, hogy „,a dualizmus korában [...] létszám tekintetében a bécsi intézmény a legjelentősebb a monarchiában, mégis a korszak során veszített viszonylagos jelentőségéből" (Patyi, 2004, 7-8.). „Más egyetemek hallgatói létszáma intenzívebben növekedett. A világháború elöestéjén a bécsi mellett tömegintézménynek tekinthető a budapesti (7513 hallgató), a lembergi [ma Lviv, Ukrajna] (5673 hallgató), a prágai cseh (4740 hallgató) és a krakkói (3030 hallgató) egyetem, hogy csak azokat említsük, ahol háromezernél több diák tanult." (Patyi, 2004, 12.) A Bécsi Egyetem méreteit jól jellemzi, hogy itt tanult Közép-Európa legnagyobb, Európa második legnagyobb lélekszámú diáksága, s az egyetem kiemelkedő szerepet játszott a délkelet- és kelet-európai értelmiség képzésében (Karády, 1990, 283-308.).

1890-ig a Bécsi Egyetemre beiratkozott diákok összlétszámát éppen az orvosi karra bekerültek száma határozta meg. 1890-től kezdve az orvosi kart választók száma folyamatosan csökkent, és 1898 után jutott mélypontjára. A kiegyezés után eddig az évig az Osztrák-Magyar Monarchia két felében szerzett orvosi oklevele- 
ket kölcsönösen elismerték, 1899. január 1-töl azonban bevezették a diplomák honosítási kötelezettségét. Ezáltal megnehezült a Bécsi Egyetemen végzett orvosok magyarországi elhelyezkedése. A beiratkozások számát tekintve érthető módon ismét mélypontot jelentett az I. világháború (Patyi, 2004, 29.).

\section{ÖSZTÖNDÍJASOK, VENDÉGHALLGATÓK, HAZATÉRÖK}

A Bécsi Egyetemre beiratkozók jelentős számban nem ott fejezték be tanulmányaikat. A budapesti Tudományegyetem orvosi karának tanácsi jegyzőkönyvei visszatérően foglalkoznak azoknak a hallgatóknak a kéréseivel, akik bécsi féléveiket, az ott tett szigorlatot budapesti tanulmányaikba kérték beszámítani. A bécsi tanulmányok komoly szerepet játszottak kiváló magyarországi orvosi életpályák felépítésében.

Az orvoskaron elnyerhető ösztöndíjak között volt a Bene-ösztöndíj is. A Pesten és Bécsben tanult Bene Ferenc doktor végrendeletileg alapítványt létesített orvosnövendékek külföldi tanulmányainak segítésére. Bene maga is hónapokat töltött Franciaországban, Németországban és Angliában. A pesti egyetem patológiaprofesszora lett, 1810-ben rektor, 1831-ben a Magyar Tudományos Akadémia tagja. Számos fontos orvostudományi munkát írt (Hőgyes, 1896, 853.). Az 1879/80-as tanévre meghirdetett Bene-ösztöndíjra jelentkezők közül az a volt hallgató, Haberern Jonathán Pál (1855-1936) került az első helyre, aki „orvosi tanulmányait kiváló szorgalommal és előmenetellel legnagyobb részben a budapesti, részben pedig a bécsi és müncheni egyetemen végezte, medicinae universae doctor oklevelét pedig egyetemünkön nyerte" (Protocolla, I.a.5., 144.). Így foglalt állást az a bizottság, melynek előadója id. Bókai János professzor volt, tagjai között pedig többek mellett szerepelt Korányi Frigyes (1828-1913) egyetemi ny. r. tanár, az egyetem talán leghíresebb, később bárói rangra emelt professzora is. Haberern később a budapesti Tudományegyetem magántanára, a Szent Rókus Kórház osztályvezető sebész föorvosa, s udvari tanácsos lett.

Ösztöndíjak elnyeréséhez jól jött a bécsi publikáció is. 1881-ben utazási ösztöndijért folyamodott Lechner Károly (1850-1922), a Schwartzer Ferenc (1818-1889) által alapított elmegyógyászati intézet orvosa, később elmegyógyász professzor, kolozsvári rektor és akadémikus, akinek pályázatát egyebek mellett egy Bécsben, frissen megjelent, „,77 sürűn nyomtatott lapos dolgozata” juttatta sikerre.

A budapesti orvosi kar mindkét pályázó kérelmét a Schordann-féle alapítványból „utaztató” ösztöndíjjal is támogatta (Protocolla, I.a.6., 119-121.). Schordann Zsigmond (1794-1862) Bécsben és Pesten tanult orvos, a pesti egyetem élettanés anatómia-, utóbb biológiaprofesszora lett. 1861-es végrendeletében vagyona $49 \%$-át az orvosi kar által kezelendő alapítványokra hagyta. Az egész hagyaték 28\%-a tanulmányi célokat szolgált, szegény sorban élő fiatal orvosnövendékek 
egy féléves bécsi, majd egy féléves berlini vagy párizsi orvosi tanulmányait tette lehetővé (Hőgyes, 1896, 388-389., 826-832.; Győry, 1936, 524-526.). Az ösztöndíjat indokolt esetben meg is lehetett hosszabbítani, ahogyan ez Lenhossék József professzor ajánlására Mihálkovics Géza (1844-1899) esetében, 1872-1874ben történt. Mihálkovics ,a letelt egy év alatt részint a bécsi, részint a lipcsei egyetemen a bonc- és a szövettannal sikeresen foglalkozott, s kifejtett szorgalma és tehetségei reményt nyújtanak, hogy idejét a külföldi intézetekben sikeresen fogja felhasználni”. Az ösztöndíj a folyamodó számára az 1872/73-as tanév nyári és az 1873/74-es tanév téli félévére „megadományoztat[ott]” (Protocolla, I.a.5., 190-191.). Mihálkovics később Budapesten anatómus professzor és az MTA tagja lett, 1892 és 1894 között az orvosi kar dékánja, 1898-1899-ben az egyetem rektora volt (Tulassay, 2014, 109.).

A budapesti orvosi kar számos ösztöndíjtípus révén erőteljesen támogatta tanárainak külföldi továbbképzését. A budapesti egyetemi orvostanárok külföldi útjának magyar állami támogatásában a korábbi bécsi résztanulmányok fontos szerepet játszottak. Plósz Pál (1844-1902) egyetemi ny. rk. tanár, később akadémikus, aki „orvosi tanulmányait Budapesten és részben Bécsben végezte [...] az 1869-70 tanévben állami segélylyel a tübingai egyetemre küldetett behatóbb vegyészet tanulmányok tétele végett" (Protocolla, I.a.7., 118.). A bécsi tanulmányok orvosegyetemi állások elnyerésekor is a pályázók segítségére voltak. Korányi Frigyes (1827-1913) professzor ajánlására a budapesti „II. belgyógyászati kórodára” került „díjazatlan gyakornokként” a frissen végzett Machik Lajos, akiről Korányi megjegyezte, hogy „Folyamodó tanulmányait a budapesti, s egy éven át a bécsi egyetemen végezte kitünő szorgalommal" (Protocolla, I.a.7., 134.; vö. Hőgyes, 1896, 278.).

A budapesti orvosi kar - önérzetesen - nem támogatta azok külföldi tanulmányút iránti kérelmét, akik a hazai lehetőségeket nem használták ki. Major Ferenc orvostanhallgató ösztöndíj folyamodványát a kari tanács a következő indokkal utasította el: „Folyamodó nem mutatván ki, hogy mindazon segédeszközöket kimerítette volna, melyek az említett tárgyban kiképzésére egyetemünkön rendelkezésére állanak, a kért utazó-ösztöndíjra nem ajánltatik" (Protocolla, I.a.6., 167.).

A bécsi tanulmányok budapesti beszámítása az I. világháború után is rendszeres ügye maradt az Orvoskarnak. Az 1920 nyarán rögzített jegyzőkönyv szerint a szegedi „Rök [sic!, helyesen Reök] Iván [1894-1967] orvostanhallgató az őszel [sic!] Bécsbe utazván ott két félévet hallgatott. [...] Most kéri két bécsi félévének teljes beszámítását" (Protocolla, I.a.46., 766.). Reök a Tanácsköztársaság alatt részt vett az egyetemi hallgatók mozgalmaiban, ezért kellett orvosi tanulmányait Bécsben befejeznie. A II. világháborút követö években élénken részt vett a politikai közéletben Budapesten, egyik vezetője lett az 1948-ban feloszlatott Független Kisgazdapártnak. 
Ugyancsak két félévet hallgatott Bécsben Rosenfeld Mátyás, ott tette le II. orvosi szigorlatát is, s mindennek beszámítását kérelmezte Budapesten. Szigorlata beszámításához a kar nem járult hozzá (Protocolla, I.a.46., 710.).

A Tanácsköztársaságot követő ellenforradalom legveszélyesebb évében nagyszámú hallgató folytatta tanulmányait külföldön, ezek ott végzett féléveinek és vizsgáinak beszámítása politikai kérdéssé vált. A jobboldali professzorok egy része, így a bel- és ideggyógyász Jendrassik Ernő (1858-1921) akadémikus, aki fiatalon maga is dolgozott bécsi kórházakban, 1919 végén egyenesen azt javasolta, ,hogy a budapesti egyetem hallgatóinak kényszerü veszteségével szemben senkinek se számíttassék be külföldi féléve vagy vizsgája”. A konzervatív tudós ekkortájt jellegzetes hazafias retorikája szerint „Evvel tartozunk a mi fiainknak, kiknek nem volt módjában a külföldi tartózkodás, még inkább azoknak, akik az országot nagy bajában el nem hagyva, a törvényes rend helyreállításában segédkeztek" (Protocolla, I.a.46., 170-171.).

A magyar diákok bécsi tanulmányainak legfontosabb oka 1919 után a magyar Numerus clausus törvény volt. Az európai kontinens első antiszemita törvénye kvótarendszert vezetett be. A felsőfokú képzésben a zsidók létszáma csak 6\%-os lehetett, a magyarországi népesség arányaihoz igazodva. Ez a törvény nagyban befolyásolta a külföldi egyetemválasztást, munkavállalást. Magyarország így számos kiváló szakembert és müvészt veszített el (Frank, 2015², 67-86.).

\section{EGYÜTTMÜKÖDÉSEK}

\section{Magyar professzorok Bécsben}

Semmelweis Ignác (1818-1865) a bécsi egyetem dísze lett: szobra ott áll az egyetem árkádsorral koszorúzott díszudvarában. Az „anyák megmentője” az aszepszis bevezetésével jelentősen csökkentette a gyermekágyi láz okozta halálozási arányt. A klórmész segítségével meg tudta előzni a gyermekágyi lázat. Kötelezővé tette a kórtermek rendszeres takarítását, szellőztetését, napoztatását és a gyakori ágyhuzatcserét. A szennyes ágynemü takarékosságból történő felhúzását elbocsátással büntette.

Semmelweis Bécsben kapta meg orvosdoktori diplomáját 1844. május 21-én. Ugyanott szülészmester (1844) és egy évvel később sebészdoktor (1845) is lett. Azonnal tanársegédi állást kapott Johann Klein (1788-1856) professzor szülészeti klinikáján, a bécsi Allgemeines Krankenhausban. 1848 tavaszán tagja lett a bécsi forradalmi Nemzeti Gárdának. Bécsi tanársegédi megbízatása 1849. március 20-án lejárt, 1850 októberében hazatért, és 1851-től a pesti Szent Rókus Kórház szülészeti osztályának vezetője lett. 1860-ban Bécsben adatta ki (1861-es évszámmal megjelenő), német nyelvü könyvét a gyermekágyi lázról: Die Aetiologie, der 
Begriff und die Prophylaxis des Kindbettfiebers címmel. Tanait a korabeli orvosi közvélemény elutasította. Halálának pontos körülményei máig ismeretlenek. Lehetséges, hogy a gyógyító munkája során szerzett szifilisz miatt utalták a döblingi elmegyógyintézetbe, ahol az erősen agresszívvé vált beteget ápolói valószínüleg agyonverték (Lesky, 1964; Kapronczay, 2015).

Egy másik jelentős, részben magyar származású tudós, a Nobel-díjas Bárány Róbert (1876-1936) Magyarországról áttelepült családban, Bécsben született, s a Bécsi Egyetemen szerzett orvosi diplomát 1900-ban. 1915-ben Bárány orosz hadifogságba esett, ahonnan már nem Bécsbe, hanem Uppsalába került vissza, részben a bécsi orvosi karral meglévő konfliktusai, az őt ott ért szakmai vádak miatt.

\section{Osztrák és magyar orvostanárok együttes ülése}

Az I. világháború előtti években látványosan megélénkült a bécsi és budapesti gyermekgyógyászok kapcsolata. 1910. április 30-án és május 1-jén az osztrák gyermekorvosok magyar kollégáikat látták vendégül Bécsben, ahol együttes ülést tartottak. A gondolat a XVI. nemzetközi orvoskongresszuson fogalmazódott meg Budapesten, 1909. augusztus 29. és szeptember 4. között (Tulassay, 2014, 123.). A bécsi üléseket az ottani orvosegyesületben tartották, s ez volt az első alkalom, hogy a magyar gyermekorvosok a bécsiekkel mintegy hivatalosan találkoztak. Voltak azonban a találkozónak előzményei: 1858-ban Fr. [Franz] Mayr, a magyar származású Leopold Maximilian Politzer és Moritz Schuller Bécsben alapította meg a korszak vezető pediátriai szaklapját, a Jahrbuch für Kinderheilkundet, melynek első munkatársai között ott volt id. Bókai János (1822-1884) is. A bécsi ülésről annak egyik résztvevője, Flesch Ármin (1878-1953), később a budapesti Madarász utcai Csecsemő- és Gyermekkórház alapító igazgatója, egyetemi c. rk. tanár írt részletes beszámolót az Orvosi Hetilapba (Flesch, 1910).

Egy évvel később, 1911-ben Theodor Escherich (1857-1911) bécsi profeszszor, a nemzetközileg elismert bakteriológus látogatott el budapesti kollégáihoz. Escherich nyomban ezután bekövetkező halála megakadályozta a bécsi kongreszszus tervezett, évenkénti folytatását. Utóda az új bécsi gyermekklinikán Clemens Peter von Pirquet báró (1874-1929) lett. Von Pirquet is járt a budapesti Stefánia Szegény-gyermek Kórházban; a magyar gyermekgyógyászok közül az ifjú Kerpel-Fronius Ödönre gyakorolt nagy hatást, aki, többek között, ugyancsak Bécsben végezte tanulmányait (Tulassay, 2014, 148.). Az agykárosult gyermekekkel foglalkozó tudós egyik legismertebb munkatársa a Magyarországon született Schick Béla (1877-1967) volt, aki 1923-ig Pirquet klinikáján dolgozott, és kidolgozta a Schick-tesztet, ami a diftéria felismerését segítette. Schick 1923-ban az Egyesült Államokba emigrált, ahol később a Columbia Egyetem gyermekgyógyász professzora lett. 
1912-ben ünnepelték az osztrák gyermekgyógyászok a pozsonyi születésű Max Kassowitz (1842-1913) bécsi professzort, az ottani orvosi iskola egyik megalapítóját. Az ünnepségen tíztagú magyar gyermekgyógyász küldöttség vett részt, ifj. Bókay János budapesti professzor vezetésével. E rendezvényt a maga is Bécsben tanult Bókay (Tulassay, 2014, 109.) némileg a tervezett bécsi-budapesti kongreszszusok folytatásának tekintette.

1913-ban a német gyermekgyógyász társaság tartotta vándorgyülését Bécsben, ami után vezető lipcsei gyermekgyógyászok Budapestre látogattak, hogy megismerkedjenek az egyetemi gyermekklinikával összekapcsolt Stefánia gyermekkórházzal, és hatalmas, piros-fehér-zöld színnel díszített pálmakoszorút helyezzenek el id. Bókai János szobrán (Bókay, 1922, 119-120.).

\section{Orvostörténészek}

A 19. század legvégétől a két egyetem orvostörténészei is együttmüködtek, majdnem a hitleri Anschlußig. Ennek a rendszeres, tartós és igényes munkakapcsolatnak a motorja nádudvari Győry Tibor (1869-1938) orvostörténész volt, pályája során a Szent Rókus Közkórház belgyógyász orvosa, a budapesti tudományegyetem magántanára, c. ny. rk., végül c. ny. r. tanára. 1919 után a Népjóléti Minisztérium miniszteri tanácsosa lett, majd helyettes államtitkárként az általános és társadalom-egészségügyi ügyosztály vezetője. Győry Tibor tiszteletére és ösztönzése révén 1929. szeptember 5-én Budapesten rendezte meg kongresszusát a Deutsche Gesellschaft für Geschichte der Medizin und der Naturwissenschaften. Az eseményre több bécsi orvostörténész és orvostanár is a magyar fővárosba érkezett. Győry fő műve a Pázmány Péter Tudományegyetem történetének III. kötete, $A z$ Orvostudományi Kar története 1770-1935, amely nagy figyelmet fordított a budapesti orvosi kar bécsi kapcsolataira mind az oktatás, mind a tudományos kutatás tekintetében (Győry, 1936).

Győry Tibor évtizedeken át folyamatos munkakapcsolatban állt az osztrák orvostörténészek legjobbjaival. Levelezését - többek között az osztrák professzorokkal - a budapesti Semmelweis Egyetem Levéltára örzi (Molnár-Szögi, 2002, 153-157.).

\section{1935: Egyetemi jubileum Budapesten - bécsi részvétellel}

A Pázmány Péter Tudományegyetem 1935-ben ünnepelte alapításának 300. évfordulóját.

Ebből az alkalomból Kornis Gyula (1885-1958) rektor felelevenítette a német nyelvủ országokkal kialakult történelmi kapcsolatokat, elsőként Ausztriáról szólva. Visszatekintett a budapesti orvoskar bécsi kapcsolataira egészen a bécsi egyetem alapítása körüli időkig, melyekről szólva megjegyezte, hogy „,magyar fiatalok 
a 14. század közepétől kezdve nagy számban látogatták a bécsi egyetemet, ahol már 1366-ban bizonyíthatóan létezett a Natio Hungarorum. Ez már a bécsi egyetem első évszázadában az összes hallgató ötödét tette ki. [...] A középkorban és a reneszánsz idején számos magyar kapcsolódott a bécsi egyetem különféle tanszékeihez. A 14. században volt már ott egy Hungaros (Magyar) László nevü magyar rektor. Az utolsó magyar származású rektor a nagy anatómus, Hyrtl József volt. [...] Amikor [Pázmány] a mi egyetemünket megalapította, azonnal levélben kérte a bécsi egyetem támogatását. Mária Terézia a mi egyetemünket, $\mathrm{s}$ különösen annak orvosi karát Van Swieten javaslatainak értelmében újjászervezte. A mi még ma is érvényes egyetemi statútumunkat [a 19. század] 50-es éveiben Leo Thun gróf Bécsből írta elő. Ily módon Bécs a legutóbbi időkig kifejtette hatását a mi egyetemünk fejlődésére.” (Kornis, 1936, 193-194.)

A rektor köszöntő szavaira Leopold von Hennet báró, budapesti osztrák követ válaszolt, tisztelegve „Magyarország szellemi teljesítménye előtt”. Emlékeztetett rá, hogy Pázmány bíboros ,a bécsi, a grazi és a prágai egyetemen kapott inspirációt és tudást” és „ott helyezkedett a keresztény világnézet alapjaira”. A követ köszönetét fejezte ki, amiért a budapesti Tudományegyetem Theodor Innitzer bíboros-hercegprímás, Alfons Dopsch udvari tanácsos és Wilhelm Schmidt professzorok mellett most ,az ő mélyen tisztelt és nagyhírü barátját”, Eiselsberg professzort is az egyetem tiszteletbeli doktorává fogadta (Kornis, 1936, 201-202.).

Anton von Eiselsberg báró (1860-1939), Theodor Billroth (1829-1894) bécsi sebészeti iskolájának leghíresebb tanítványa maga is harminc éven át állt a bécsi sebészeti klinika élén. A díszdoktorrá avató beszédet a budapesti orvosi kar dékánja, Darányi Gyula tartotta, kiemelve, hogy a magyar orvostudomány milyen sokat köszönhet új díszdoktorának és általában is a Bécsi Egyetemnek (Kornis, 1936, 263-265.).

A viszonyok a hidegháború évtizedeiben rendkívül megnehezültek. Sokáig úgyszólván lehetetlenné vált az együttmüködés Béccsel, és az ottani egyetemen való továbbtanulás vagy tanítás. Ennek és a magyarországi rendszerváltozás utáni enyhülésnek a történetéhez távlatokra és a források gondos feltárására van még szükség, kül- és belföldön egyaránt. Bécs és Budapest egyetemi kapcsolattörténetének felidézése mostanában nincs híján többféle aktualitásnak sem.

\section{IRODALOM}

\section{Levéltári források}

A Semmelweis Egyetem Központi Levéltára, Budapest

Protocolla - 1/a: Protocolla sessionum Facultatis Medicae in Regia Universitate Pestinensi (A Pesti

Királyi Tudományegyetem Orvostudományi Karának tanácsülési jegyzőkönyvei) 1770-1952. 302/b: Győry Tibor iratai. Levelezés 1880-1937. 


\section{Nyomtatott források}

Bókay J. von (1922): Die Geschichte der Kinderheilkunde. Berlin: Julius Springer, https://archive. org/stream/39002079236767.med.yale.edu/39002079236767.med.yale.edu_djvu.txt

Flesch Á. (1910): A magyar és osztrák gyermekorvosok együttes ülése. Bécs, 1910. április 30.-ától május 1.-éig. Orvosi Hetilap, LIV, 30-31, Különnyomat, 1-11.

Hőgyes E. (szerk.) (1896): Emlékkönyv a budapesti királyi magyar tudomány egyetem orvosi karának multjáról és jelenéről. Budapest: Magyar Orvosi Könyvkiadó Társulat, https://library. hungaricana.hu/hu/view/KlasszikusOrvosiKonyvek_103/?pg=0\&layout=s

Kornis Gy. (szerk.) (1936): A királyi magyar Pázmány Péter Tudományegyetem alapítása 300 éves évfordulójának jubileumi évkönyve. Budapest: Királyi Magyar Egyetemi Nyomda

Patyi G. (2004): Magyarországi diákok bécsi egyetemeken és föiskolákon 1890-1918. Budapest: Eötvös Loránd Tudományegyetem Levéltára

Patyi G. - Simon Zs. - Szabó M. et al. (2015): Magyarországi diákok bécsi egyetemeken és föiskolákon 1867-1890. Budapest: Eötvös Loránd Tudományegyetem Levéltára

\section{Feldolgozások}

Buzinkay G. (1977): Az Egyetemi Nyomda és orvosi-természettudományos szakirodalmunk kialakulása. Magyar Könyvszemle, 93, 25-37. http://epa.oszk.hu/00000/00021/00297/pdf/ MKSZ_EPA00021_1977_93_01_00297.pdf

Fata M. - Kurucz Gy. - Schindling, A. (Hrsg.) (2006): Peregrinatio Hungarica. Studenten aus Ungarn an deutschen und österreichischen Hochschulen vom 16. bis zum 20. Jahrhundert. Stuttgart: Franz Steiner Verlag

Frank T. $\left(2015^{2}\right)$ : Kettős kivándorlás. Budapest-Berlin-New York, 1919-1945. Budapest: Gondolat Kiadó

Győry T., Nádudvari (1936): Az Orvostudományi Kar története 1770-1935. A királyi magyar Pázmány Péter Tudományegyetem története, III. kötet. Budapest: Királyi Magyar Egyetemi Nyomda, https://library.hungaricana.hu/hu/view/KlasszikusOrvosiKonyvek_092/?pg= 0\&layout $=\mathrm{s}$

Hanák P. (1975): Magyarország az Osztrák-Magyar Monarchiában: Túlsúly vagy függőség. In: Hanák P.: Magyarország a Monarchiában. Tanulmányok. Budapest: Gondolat Kiadó

H. Balázs É. (1973): Van Swietens Ideen und die ungarische Gesellschaft. In: Lesky, E. - Wandruszka, A. (Hrsg.): Gerard van Swieten und seine Zeit. Wien-Köln-Graz: Böhlau, 154-163. https://bit.ly/2XeLTJd

Kapronczay K. (szerk.) (2015): Semmelweis. Az elsö Semmelweis-kutató, Beretzky Endre emlékére Semmelweis Ignác halálának 150. évfordulóján. Budapest: MTA Orvostörténeti Munkabizottsága-Magyar Tudománytörténeti Intézet-Köbánya Önkormányzata, http://real.mtak. hu/25576/1/Semmelweis\%20nyomdai\%203 05 VEGLEGES.pdf

Karády V. (1990): Funktionswandel der österreichischen Hochschulen in der Ausbildung der ungarischen Fachintelligenz vor und nach dem ersten Weltkrieg. In: Karady V. - Mitter, W. (Hrsg.): Bildungsraum und Sozialstruktur in Mitteleuropa im 19. und 20. Jahrhundert. WienKöln: Böhlau, 177-205.

Lesky, E. (1964): Ignaz Philipp Semmelweis und die Wiener medizinische Schule. Wien: H. Böhlaus Nachfolger

Lesky, E. (1965): Die Wiener medizinische Schule im 19. Jahrhundert. Graz-Köln: Hermann Böhlaus Nachfolger 
Molnár L. - Szögi L. (2002): A Semmelweis Orvostudományi Egyetem Levéltára 1770-1999. Repertórium. Budapest: Semmelweis Egyetem, https://docplayer.hu/4414070-Molnar-laszlo-szogi-laszlo-a-semmelweis-orvostudomanyi-egyetem-leveltara-1770-1999-repertorium.html

Schultheisz E. (2005): A belorvostan tanítása a nagyszombati egyetemen. In: Schultheisz E. - Magyar L. A.: Orvosképzés a nagyszombati egyetemen 1769-1777. (Magyar Tudománytörténeti Szemle Könyvtára, 55., szerk. Gazda I.) Piliscsaba: Magyar Tudománytörténeti Intézet

Szögi L. (2000): Zur Rolle der Wiener Universität im ungarischen Hochschulwesen von den Anfängen bis zum ersten Weltkrieg. In: Größing, H. - Kernbauer, A. - Mühlberger, K. (Hrsg.): „Mensch - Wissenschaft - Magie”. Mitteilungen der Österreichischen Gesellschaft für Wissenschaftsgeschichte, 20, 203-208.

Szögi L. (2015): Ungarländische Studenten an Wiener Universitäten und Hochschulen 1867-1890. In: Patyi G. - Simon Zs. - Szabó M. et al.: Magyarországi diákok bécsi egyetemeken és föiskolákon 1867-1890. Budapest: Eötvös Loránd Tudományegyetem Levéltára

Tulassay T. (2014): Az Ötpacsirta utczától a Gólya utczáig. A Bókay-klinika 175 éve. Budapest: Semmelweis Kiadó 